\title{
Australian Journal of \\ Sustainability of the grey water footprint (GWF) for cultivation of onion in the Brazilian semi-arid regions
}

\author{
Rigoberto Moreira de Matos, Vitória Ediclécia Borges, Antônio Suassuna de Lima, Patrícia Ferreira \\ da Silva*, José Dantas Neto, Vera Lúcia Antunes de Lima
}

\author{
Federal University of Campina Grande, Academic Unit of Agricultural Engineering, Campina Grande, 58.109- \\ 970, Paraíba, Brazil
}

\section{*Corresponding author: patrycyafs@yahoo.com.br}

\begin{abstract}
The grey water footprint (GWF) is defined as the volume of freshwater that is required to dilute pollutants to make them harmless. The objective of this study was to evaluate the grey water footprint and its sustainability for onion cultivation in the Brazilian semiarid regions. The work was developed in the Brazilian semi-arid region in an area corresponding to 10 thousand hectares of onion cultivation under surface irrigation. A survey of the main pollutants was carried out, in addition to the environmental conditions of soil and climate, soon after using mathematical models to estimate the grey water footprint and sustainability. The agrochemicals Ronstar 250 BR, Dicarzol 500 PS and Sportak 450 CE are classified as having the highest grey water footprint for onion cultivation in the Brazilian semi-arid region; thus requiring a higher volume of freshwater for pollutants dilution to convert them to harmless. It is recommended to replace these agrochemicals with others of smaller GWF. According to the obtained results, it can be concluded that the grey water footprint is an efficient indicator in monitoring the impact of man on the environment. The semi-arid regions of Brazil classified as sustainable for the cultivation of irrigated onions.
\end{abstract}

Keywords: Allium cepa, agrochemicals, Sustainability analysis.

Abbreviations: A _ fraction of leaching or flow (dimensionless); A_ Fraction of leaching; A_ Fraction of leaching-flow; Apl _the variable that represents the amount of chemical substances applied to the soil in a given process (mass / time); B $_{-}$referring to the content of organic matter (Good); B $_{-}$referring to the high precipitation intensity of the region (low); Cmax _ Maximum acceptable concentration (mass / volume);Cmax _Maximum allowable concentration value; Cmax_ Maximum permissible concentration of the pollutant in the receiving aquatic environment $\left(\mathrm{kg} \mathrm{m}^{-3}\right)$; Cnat_Natural concentration of the pollutant in the receiving aquatic environment $\left(\mathrm{kg} \mathrm{m}^{-3}\right)$;Cnat _Natural concentration of the receiving body (mass / volume);CP _Concentration of the product; NA_Number of applications; F_ referring to soil texture (franc); IP _ Precipitation intensity;Koc_coefficient of partition of organic

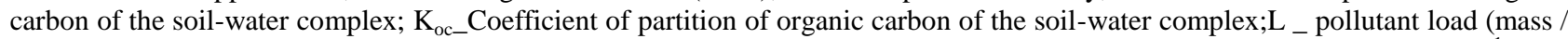
time); L_pollutant load of the substance; WPL_ Water Pollution Level; $\mathrm{P}_{-}$Precipitation; $\mathrm{P}_{-}$Productivity of the crop $\left(\mathrm{t}\right.$ ha $\left.{ }^{-1}\right) ; \mathrm{PE}_{-}$ Persistence relevant to disposal (50\% of the duration); GWF_Annual water footprint of the substance due to farm of 1 hectare; PL_ Persistence relevant to leaching (50\% of the duration time); PM -Management practices relevant to the outflow the runoff; Freal _ the actual flow of a basin;R_ referring to the cultural practices relevant to the outflow (Bad); Si _leaching potential-flow; TAPC_ Commercial product application rate; TAS _ rate of application of the substance; TQ_rate of application of chemical substances per hectare $\left(\mathrm{kg} \mathrm{ha}^{-1}\right)$; TSE_Soil texture relevant to leaching to runoff;T tapl_ Total rate of application of the substance; Wi factor weight; $\alpha$ max _maximum leaching fraction; $\alpha$ min _ fraction of leaching / minimum flow; $\Sigma G W F \_t o t a l$ sum of grey water footprints.

\section{Introduction}

The water footprint is a multidimensional indicator of water use. This encompasses, not only the direct use by a particular consumer or producer, but also as a measure of indirect use. It can be considered as a comprehensive index when it comes to the appropriation of water resources (Zhao et al., 2009; Silva et al., 2013).

According to Hoekstra et al. (2011) the grey water footprint (GWF) refers to the pollution of the water, which is considered as an indicator of the degree of pollution of freshwater in a process that can be engaged in the step of the production process of any product or service. In this context, the grey water footprint is characterized as the volume of freshwater required to dilute the load of pollutants, taking into consideration the natural concentrations and in the environmental standards in place (Hoekstra and Chapagain, 2007).

Hoekstra (2009) and Silva et al. (2015) reported that pollution of the waters can be expressed in terms of the volume of water needed to dilute pollutants so that they become ineffective.

Several studies have been carried out to understand effect of water footprint and excessive use of agrochemicals on various parts of plant species and all phases of the production process of crops (Salmoral et al., 2011; Mekonnen and Hoekstra, 2015; Rivas Ibáñez et al., 2017; Nyambo and 
Wakindiki, 2015; Roux et al., 2016; Dourte and Fraisse, 2012).

Among vegetable crops in Brazil, onion has contributed significantly to the pollution of water resources, since the crop is attacked by various pests and diseases that imply lower productivity per area cultivated. Due to numerous and constant use of agrochemicals, these in turn, can be highly pollutant to the environment, particularly to water resources. In this way, the study of the grey footprint for onion culture is essential for reduction of the pollution during the production process, (Faria et al., 2012; Rivas Ibáñez et al., 2017; Dourte and Fraisse, 2012; Hoekstra et al., 2011a). According to Van Oel and Hoekstra (2012), the analysis of the sustainability of a water footprint entirely depends on the local factors such as the characteristics of water in the region, the amount of chemical applied during the production process, climatic conditions, management adopted in the application of agrochemicals, the number of courses of water and water quality existing.

Hoekstra (2009) stated that a large water footprint can be considered sustainable in areas rich in water, while a small water footprint can compromise the sustainability in areas with scarcity of water resources, a fact observed in the semiarid region of Brazil with problems of water scarcity. The use of freshwater is totally related to the problems of scarcity and pollution, a fact that occurs mainly by the use of agrochemicals in agriculture and the pollutants released in the air and in the water by industries (Hoekstra and Chapagain, 2007).

The control of pollution caused by the indiscriminate use of agrochemicals is of great relevance for the preservation of the water resources in the semi-arid region of Brazil to ensure sustainability for the agriculture and water resources. Due to substantial importance of preservation of water resources and economical value of vegetable crops, especially onion, the objective of the present work is to evaluate the grey water footprint and its sustainability for the cultivation of the onion in the Brazil semi-arid region.

\section{Results and Discussion}

\section{The main agrochemicals used in onion cultivation and their pollution potential}

The main agrochemicals being used in onion cultivation as well as the rates of applications in the region of the semi-arid of Brazil are presented in Table 1. Note that among the main agrochemicals in onion culture, the fungicide Dithane PM is the one that has the highest rate of application. This means that this product has the largest amount of chemical applied during the year. Pinheiro et al. (2011) report that a chemical to be considered suitable for crops should be lethal to the target pests, diseases and weeds but not non-target species including man, water and resources of soil. However, this is not the case, as the controversy of use and abuse of agrochemicals has emerged. The inappropriate use of chemicals has generated great problems to human, crops, water, soil and the environment (Aktar et al., 2009).

The inappropriate use of agrochemicals compounds has caused concerns about contamination of the environment especially due to excessive and prolonged application of these compounds. Therefore, farmers and agricultural industries should take precautions for the application and waste management of chemicals from the various sources and the provision of proper end of these wastes, without compromising the environment (Tavella et al., 2011).
Rivas Ibáñez et al. (2017) highlight that it is of great need to develop standards for applying agrochemicals to the cultivated species, so that the number of applications associated with the concentration of the commercial product and application rate of the substance will not cause impact to the environment, and consecuently water and human health (Bernabeu et al., 2011; Gibson and Koifman, 2008; Molozzi et al., 2006).

\section{Leaching and potential flow of the chemicals}

The factors that influence the potential flow of leaching of the agrochemical are presented in Table 2. It is apparent that the chemical properties of the soil, climate, and plant influences on the factor that determines the potential for leaching and runoff of the substance in agrochemicals. The soil texture in semi-arid region of Brazilian has been classified as high leaching for the application of agrochemicals in onion cultivation. This soil has also been classified as low organic content. Although the intensity of precipitation in these soils are low, but they might be regarded as high flow potential due to their high leaching value (Table 2).

These values (leaching and flow potential) vary from 0 to 1 , whereas zero when the region has low potential for leaching and 1 being considered to be of very high potential. With regard to the chemical properties of the agrochemicals, such as partition coefficient of organic carbon in the complex of soil-water, persistence is relevant to leaching and runoff with $50 \%$ of the length of time. It is possible to observe that these also are classified as the factor that relates to the potential for leaching and runoff (Table 2).

The values and weights of agrochemicals related to the chemical properties, environmental factors and cultural practices influence the flow of leaching and runoff. Taking into consideration the soil texture, the organic matter content looks good, the intensity of precipitation is low and cultural practices relating to poor runoff (Table 2).

Damalas et al. (2011), reported that the amount of agrochemicals that migrates from its area of application is directly affected by the specific chemical properties and are linked to their propensity to binding to colloids of soil, vapor pressure, water solubility, leaching potential, dilution in the water precipitated and its resistance to degradation over time. Pinheiro et al. (2011) reported that the environmental factors are more dynamic in agrochemicals currently being used in the cultivation of onion. There is spatial and temporal heterogeneity, which influence the spatial distribution, either in the vertical direction or in the horizontal direction of the soil and time, occurring dissipation of the product, or by degradation, evaporation or absorption of bodies.

The transport processes among environmental compartments, leaching and surface runoff are the ones that deserve to be highlighted. In this way, the runoff favors the contamination of surface waters through the transport of chemicals adsorbed to the particles of eroded soil or dissolved in water (Spadotto et al., 2004). The leaching of agrochemicals through the soil profile tends to result in the contamination of groundwater, and in this case, the chemicals are carried in solution along with the water that feeds the aquifer (Damalas et al., 2011).

To occur the dispersion of this load of pollutants in the onion culture, it is necessary that the amount of water present in the basin is sufficient to mitigate the effects of the agrochemicals to reduce the impacts of this on the environment and consequently to human life. 
Table 1. Application rate of the main agrochemicals used in onion culture in the semi-arid of Brasil.

\begin{tabular}{lllllll}
\hline Cultivation (1) & Agrochemicals (2) & Class (3) & $\begin{array}{l}\text { TAPC* }\left(\mathrm{L} \mathrm{ha}^{-1}\right) \\
(4)\end{array}$ & $\begin{array}{l}\mathrm{CP} *\left(\mathrm{~g} \mathrm{~L}^{-1}\right) \\
(5)\end{array}$ & $\begin{array}{l}\mathrm{NA}^{*} \\
(6)\end{array}$ & $\begin{array}{l}\mathrm{TAS}^{*}(\mathrm{t} \mathrm{ha} \\
7=(4 \times 5 \times 6)\end{array}$ \\
\hline Onion & Ronstar 250 BR & Herbicide & 3.5 & 250.0 & 1.0 & $8.75 \times 10^{-4}$ \\
& Targa 50 CE & Herbicide & 1.5 & 50.0 & 1.0 & $7.5 \times 10^{-5}$ \\
& Totril & Herbicide & 1.0 & 335.0 & 1.0 & $3.35 \times 10^{-4}$ \\
& Dicarzol 500 SP & Insecticide & $1.0 \mathrm{~kg} \mathrm{ha}^{-1}$ & $582 \mathrm{~g} \mathrm{~kg}^{-1}$ & 6.0 & $3.49 \times 10^{-3}$ \\
& Karate 50 CE & Insecticide & 0.2 & 50.0 & 6.0 & $6.0 \times 10^{-5}$ \\
& Sportak 450 CE & Fungicide & 1.5 & 450.0 & 4.0 & $2.7 \times 10^{-3}$ \\
& Dithane PM & Fungicide & $2.0 \mathrm{~kg} \mathrm{ha}^{-1}$ & $800 \mathrm{~g} \mathrm{~kg}^{-1}$ & 4.0 & $6.4 \times 10^{-3}$ \\
& Benlate 500 & Fungicide & $2.0 \mathrm{~kg} \mathrm{ha}^{-1}$ & $500 \mathrm{~g} \mathrm{Kg}^{-1}$ & 4.0 & $4.0 \times 10^{-3}$ \\
\hline
\end{tabular}

*TAPC - Commercial product application rate; CP - Concentration of the product; NA - Number of applications; e TAS - rate of application of the substance.

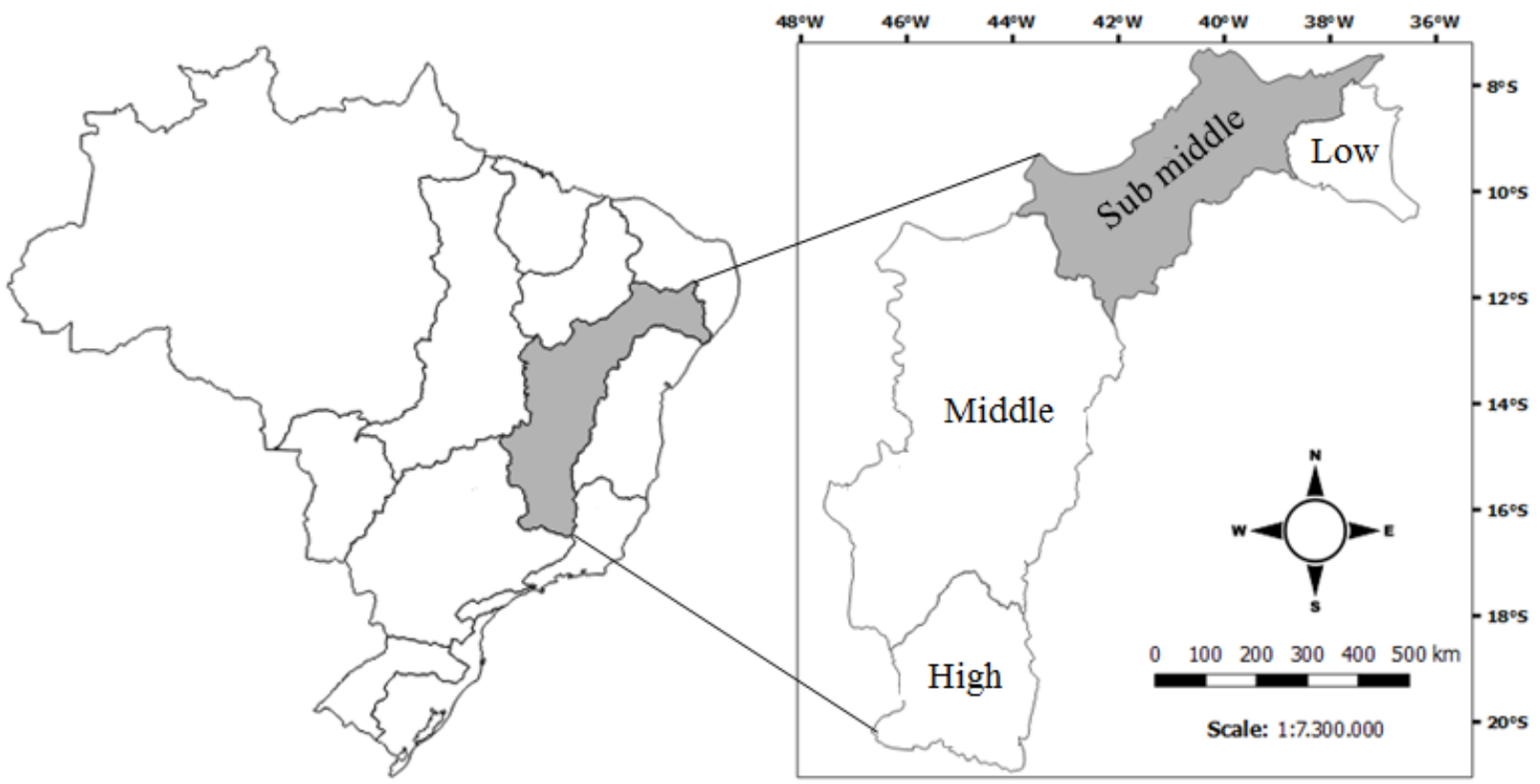

Fig 1. Location of the study area within the São Francisco river basin in the semi-arid region of Brazil.

Table 2. Factors influencing the leaching potential of agrochemicals. The state of the factor determining leaching and flow potential is expressed as a value between 0 and 1 .

\begin{tabular}{|c|c|c|c|c|c|c|c|}
\hline \multicolumn{8}{|l|}{ Agrochemicals } \\
\hline \multirow[t]{3}{*}{ Category } & & \multirow[t]{3}{*}{ Factor } & $\begin{array}{l}\text { Potential } \\
\text { leaching and } \\
\text { flow }\end{array}$ & Very low & Low & High & $\begin{array}{l}\text { Very } \\
\text { high }\end{array}$ \\
\hline & & & Valor $(\mathrm{S}) \rightarrow$ & 0.00 & 0.33 & 0.67 & 1.00 \\
\hline & & & Weight (w) & & & & \\
\hline \multirow{3}{*}{\multicolumn{2}{|c|}{ Chemical property }} & $\mathrm{K}_{\mathrm{oc}}\left(\mathrm{L} \mathrm{kg}^{-1}\right)$ & 20 & $>1000$ & $1000-200$ & $200-50$ & $<50$ \\
\hline & & $\mathrm{PL}\left(\mathrm{D}_{\mathrm{T} 50}\right.$ dias $)$ & 15 & $<10$ & $10-30$ & $30-100$ & $>100$ \\
\hline & & $\mathrm{PE}\left(\mathrm{D}_{\mathrm{T} 50}\right.$ dias $)$ & 10 & $<10$ & $10-30$ & $30-100$ & $>100$ \\
\hline \multirow{6}{*}{$\begin{array}{l}\text { Environmental } \\
\text { factors }\end{array}$} & & TSL & 15 & Clay & Silt & Franc & Sand \\
\hline & Soil & TSE & 10 & Sand & Franc & Silt & Clay \\
\hline & & Content $\mathrm{MO} *($ dag. & 10 & Great & Good & & Low \\
\hline & & $\left.\mathrm{Kg}^{-1}\right)$ & & $>7.00$ & $4.01-7.00$ & $\begin{array}{l}\text { Average } \\
2.01-4.00\end{array}$ & $<2.00$ \\
\hline & Climate & IP (mm) & 5 & Low & Moderate & High & $\begin{array}{l}\text { Very } \\
\text { high }\end{array}$ \\
\hline & & $\mathrm{P}(\mathrm{mm})$ & 5 & $<600$ & $600-1200$ & $1200-1800$ & $>1800$ \\
\hline Cultural Practices & & PM & 10 & Great & Good & $\mathrm{Bad}$ & Poor \\
\hline
\end{tabular}


Table 3. Values and weights by agrochemicals of factors related to chemical properties, environmental factors and cultural practices, which influence leaching and flow in the study area.

\begin{tabular}{|c|c|c|c|c|c|c|c|c|c|}
\hline Agrochemicals & $\begin{array}{c}\mathrm{K}_{\mathrm{oc}} \\
\left(\mathrm{L} \mathrm{kg}^{-1}\right) \\
20^{*}\end{array}$ & $\begin{array}{c}\text { PL (dias) } \\
15^{*}\end{array}$ & $\begin{array}{c}\text { PE (dias) } \\
10^{*}\end{array}$ & $\begin{array}{l}\text { TSL } \\
15 * \\
\end{array}$ & $\begin{array}{l}\text { TSE } \\
10 * \\
\end{array}$ & $\begin{array}{c}\mathrm{MO} \\
\left(\operatorname{dag~Kg}^{-1}\right) \\
10^{*}\end{array}$ & $\begin{array}{l}\text { IP } \\
5^{*} \\
\end{array}$ & $\begin{array}{c}\mathrm{P} \\
(\mathrm{mm}) \\
5^{*}\end{array}$ & $10 *$ \\
\hline Ronstar $250 \mathrm{BR}$ & $\begin{array}{c}>1000.0 \\
(0.00)\end{array}$ & $\begin{array}{l}502.0 \\
(1.00)\end{array}$ & $\begin{array}{c}17.9 \\
(0.33)\end{array}$ & $\begin{array}{c}F \\
(0.67)\end{array}$ & $\begin{array}{c}\mathrm{F} \\
(0.33)\end{array}$ & $\begin{array}{c}\mathrm{B} \\
(0.33)\end{array}$ & $\begin{array}{c}\text { B } \\
(0.00)\end{array}$ & $\begin{array}{l}542.0 \\
(0.00)\end{array}$ & $\begin{array}{c}\mathrm{R} \\
(0.67)\end{array}$ \\
\hline Targa 50 CE & $\begin{array}{l}540.0 \\
(0.33)\end{array}$ & $\begin{array}{c}45.0 \\
(0.67)\end{array}$ & $\begin{array}{c}39.0 \\
(0.67)\end{array}$ & $\begin{array}{c}\mathrm{F} \\
(0.67)\end{array}$ & $\begin{array}{c}\mathrm{F} \\
(0.33)\end{array}$ & $\begin{array}{c}\text { B } \\
(0.33)\end{array}$ & $\begin{array}{c}\text { B } \\
(0.00)\end{array}$ & $\begin{array}{l}542.0 \\
(0.00)\end{array}$ & $\begin{array}{c}\mathrm{R} \\
(0.67)\end{array}$ \\
\hline Totril & $\begin{array}{l}310.0 \\
(0.33)\end{array}$ & $\begin{array}{c}10.0 \\
(0.33)\end{array}$ & $\begin{array}{c}0.67 \\
(0.00)\end{array}$ & $\begin{array}{c}F \\
(0.67)\end{array}$ & $\begin{array}{c}\mathrm{F} \\
(0.33)\end{array}$ & $\begin{array}{c}\text { B } \\
(0.33)\end{array}$ & $\begin{array}{c}\text { B } \\
(0.00)\end{array}$ & $\begin{array}{l}542.0 \\
(0.00)\end{array}$ & $\begin{array}{c}\mathrm{R} \\
(0.67)\end{array}$ \\
\hline Dicarsol 500 PS & $\begin{array}{l}<50.0 \\
(1.00)\end{array}$ & $\begin{array}{c}9.4 \\
(0.00)\end{array}$ & $\begin{array}{c}0.3 \\
(0.00)\end{array}$ & $\begin{array}{c}F \\
(0.67)\end{array}$ & $\begin{array}{c}\mathrm{F} \\
(0.33)\end{array}$ & $\begin{array}{c}\text { B } \\
(0.33)\end{array}$ & $\begin{array}{c}\text { B } \\
(0.00)\end{array}$ & $\begin{array}{l}542.0 \\
(0.00)\end{array}$ & $\begin{array}{c}R \\
(0.67)\end{array}$ \\
\hline Karate $50 \mathrm{CE}$ & $\begin{array}{c}>1000.0 \\
(0.00)\end{array}$ & $\begin{array}{l}175.0 \\
(1.00)\end{array}$ & $\begin{array}{c}0.24 \\
(0.00)\end{array}$ & $\begin{array}{c}F \\
(0.67)\end{array}$ & $\begin{array}{c}\mathrm{F} \\
(0.33)\end{array}$ & $\begin{array}{c}\text { B } \\
(0.33)\end{array}$ & $\begin{array}{c}\text { B } \\
(0.00)\end{array}$ & $\begin{array}{l}542.0 \\
(0.00)\end{array}$ & $\begin{array}{c}\mathrm{R} \\
(0.67)\end{array}$ \\
\hline Sportak $450 \mathrm{CE}$ & $\begin{array}{l}500.0 \\
(0.33)\end{array}$ & $\begin{array}{l}120.0 \\
(1.00)\end{array}$ & $\begin{array}{c}1.0 \\
(0.00)\end{array}$ & $\begin{array}{c}F \\
(0.67)\end{array}$ & $\begin{array}{c}\mathrm{F} \\
(0.33)\end{array}$ & $\begin{array}{c}\text { B } \\
(0.33)\end{array}$ & $\begin{array}{c}\text { B } \\
(0.00)\end{array}$ & $\begin{array}{l}542.0 \\
(0.00)\end{array}$ & $\begin{array}{c}\mathrm{R} \\
(0.67)\end{array}$ \\
\hline Dithane PM & $\begin{array}{l}998.0 \\
(0.33)\end{array}$ & $\begin{array}{c}0.1 \\
(0.00)\end{array}$ & $\begin{array}{c}0.2 \\
(0.00)\end{array}$ & $\begin{array}{c}\mathrm{F} \\
(0.67)\end{array}$ & $\begin{array}{c}\mathrm{F} \\
(0.33)\end{array}$ & $\begin{array}{c}\text { B } \\
(0.33)\end{array}$ & $\begin{array}{c}\text { B } \\
(0.00)\end{array}$ & $\begin{array}{l}542.0 \\
(0.00)\end{array}$ & $\begin{array}{c}\mathrm{R} \\
(0.67)\end{array}$ \\
\hline Benlate 500 & $\begin{array}{c}>1000.0 \\
(0.00)\end{array}$ & $\begin{array}{c}67.0 \\
(0.67) \\
\end{array}$ & $\begin{array}{c}<1 \\
(0.00) \\
\end{array}$ & $\begin{array}{c}F \\
(0.67) \\
\end{array}$ & $\begin{array}{c}F \\
(0.33)\end{array}$ & $\begin{array}{c}\text { B } \\
(0.33) \\
\end{array}$ & $\begin{array}{c}\text { B } \\
(0.00) \\
\end{array}$ & $\begin{array}{l}542.0 \\
(0.00) \\
\end{array}$ & $\begin{array}{c}\mathrm{R} \\
(0.67) \\
\end{array}$ \\
\hline
\end{tabular}

Table 4. Grey water footprint (GWF) due to the agricultural exploitation of agrochemicals used in one hectare of onion culture in the semi-arid region of the Brazil.

\begin{tabular}{|c|c|c|c|c|c|c|c|}
\hline Cultivation (1) & $\begin{array}{l}\text { Agrochemicals } \\
\text { (2) }\end{array}$ & $\begin{array}{c}\alpha \\
(3) \\
\end{array}$ & $\begin{array}{l}\text { Ttapl (t) } \\
(4)\end{array}$ & $\begin{array}{c}\mathrm{L}(\mathrm{t}) \\
(5=3 \times 4)\end{array}$ & $\begin{array}{c}C \max \left(\mathrm{t} \mathrm{m}^{-3}\right) \\
(6)\end{array}$ & $\begin{array}{c}\mathrm{GWF}^{*}\left(\mathrm{~m}^{3}\right) \\
(7=5 / 6)\end{array}$ & $\operatorname{GWF}\left(\mathrm{m}^{3} \mathrm{t}^{-1}\right)$ \\
\hline \multirow{8}{*}{ Onion } & Ronstar $250 \mathrm{BR}$ & 0.042 & $8.7 \times 10^{-4}$ & $3.7 \times 10^{-5}$ & $1.0 \times 10^{-10}$ & $3.7 \times 10^{5}$ & 18375.0 \\
\hline & Targa $50 \mathrm{CE}$ & 0.047 & $7.5 \times 10^{-5}$ & $3.5 \times 10^{-6}$ & $6.0 \times 10^{-10}$ & $5.9 \times 10^{3}$ & 293.8 \\
\hline & Totril & 0.035 & $3.3 \times 10^{-4}$ & $1.2 \times 10^{-5}$ & $1.0 \times 10^{-10}$ & $1.2 \times 10^{5}$ & 5862.5 \\
\hline & Dicarsol 500 PS & 0.043 & $3.5 \times 10^{-3}$ & $1.5 \times 10^{-4}$ & $1.0 \times 10^{-10}$ & $1.5 \times 10^{6}$ & 75078.0 \\
\hline & Karate $50 \mathrm{CE}$ & 0.038 & $6.0 \times 10^{-5}$ & $2.3 \times 10^{-6}$ & $1.0 \times 10^{-10}$ & $2.3 \times 10^{4}$ & 1140.0 \\
\hline & Sportak $450 \mathrm{CE}$ & 0.045 & $2.7 \times 10^{-3}$ & $1.2 \times 10^{-4}$ & $1.0 \times 10^{-10}$ & $1.2 \times 10^{6}$ & 60750.0 \\
\hline & Dithane PM & 0.030 & $6.4 \times 10^{-3}$ & $1.9 \times 10^{-4}$ & $2.2 \times 10^{-10}$ & $8.8 \times 10^{5}$ & 43835.6 \\
\hline & Benlate 500 & 0.033 & $4.0 \times 10^{-3}$ & $1.3 \times 10^{-4}$ & $1.0 \times 10^{-8}$ & $1.3 \times 10^{4}$ & 660.0 \\
\hline
\end{tabular}

(A) - Fraction of leaching-flow; Ttapl - Total rate of application of the substance; L - pollutant load of the substance; Cmax - Maximum allowable concentration value; *

GWF- Annual water footprint of the substance due to farm of 1 hectare.

Table 5. Classes and potential environmental hazard of agrochemicals.

\begin{tabular}{lcccc}
\hline Class & I & II & III & IV \\
\hline Danger & Highly dangerous & Very dangerous & Dangerous & Not too dangerous \\
\hline
\end{tabular}

Table 6. The main agrochemicals used in the cultivation of onion in the Brazilian semiarid region.

\begin{tabular}{|c|c|c|c|c|}
\hline Cultivation & Agrochemicals & Class & Toxicological classification & $\begin{array}{l}\text { Environmental hazard } \\
\text { classification }\end{array}$ \\
\hline Onion & $\begin{array}{l}\text { Ronstar } 250 \mathrm{BR} \\
\text { (Oxadiazon) } \\
\text { Targa 50 CE } \\
\text { (Quizalofope-P-Metílico) } \\
\text { Totril } \\
\text { (Octanoato Ioxinila) } \\
\text { Dicarzol } 500 \text { SP } \\
\text { (Cloridrato de Formetanato) } \\
\text { Karate } 50 \text { CE } \\
\text { (Lambda-Cialotrina) } \\
\text { Sportak } 450 \mathrm{CE} \\
\text { (Procloraz) } \\
\text { Dithane PM } \\
\text { (Mancozebe) } \\
\text { Benlate 500 } \\
(\text { Benomyl (Benzimidazol)) }\end{array}$ & $\begin{array}{l}\text { Insecticide } \\
\text { Insecticide } \\
\text { Fungicide }\end{array}$ & $\begin{array}{c}\text { II } \\
\text { Highly toxic } \\
\text { I } \\
\text { Extremely toxic } \\
\text { I } \\
\text { Extremely toxic } \\
\text { II } \\
\text { Highly toxic } \\
\text { II } \\
\text { Highly toxic } \\
\text { I } \\
\text { Extremely toxic } \\
\text { I } \\
\text { Extremely toxic } \\
\text { III } \\
\text { Moderately toxic }\end{array}$ & $\begin{array}{c}\text { III } \\
\text { Dangerous } \\
\text { II } \\
\text { Very dangerous } \\
\text { II } \\
\text { Very dangerous } \\
\text { II } \\
\text { Very dangerous } \\
\text { I } \\
\text { Highly dangerous } \\
\text { II } \\
\text { Very dangerous } \\
\text { II } \\
\text { Very dangerous } \\
\text { Not classified }\end{array}$ \\
\hline
\end{tabular}


In this way, the load of pollutants that reach the water system can be calculated using the water footprint as being the volume of the theoretical water necessary for the dilution of that same load, associated with the production of a culture, so that it becomes harmless (Ercin et al., 2012; Hoekstra et al., 2011).

\section{Properties of the agrochemical, the partition of carbon, persistence, leaching, and runoff}

The partition coefficient of organic carbon of the complex soil-water or adsorption coefficient (Koc) of the chemicals Ronstar 250 BR, Karate 50 EC, Benlate 500 is classified as very low. The agrochemicals such as Targa $50 \mathrm{EC}$, Totril, Sportak 450 EC and Dithane PM were classified as low potential. The Dicarsol 500 was classified as very high (Table $3)$.

The Ronstar 250 BR, Karate 50 EC and Sportak 450 EC were ranked as a very high persistence leaching and Targa 50 and EC Benlate 500 as of high persistence. The Totril, Dicarsol 500 and Dithane PM are low and very low persistence and leaching, respectively (Table 3). The adsorption coefficient (Koc) is defined as the value that represents the amount of organic carbon of the chemical compound that may be adsorbed to the soil. This parameter estimates the partition of a substance in the soil-water system, e.g. how much of it has affinity with the ground without being dragged through the water (Canuto et al., 2010).

Sometimes, the agrochemicals classified as very low and low are considered as the greatest risks of contamination to the environment (Damalas et al., 2011). Products that have a low Koc with low tendency to adsorb on the soil can easily reach the water bodies and; therefore, have greater mobility and high solubility. They will increase the likelihood of contamination of groundwater (Carbo et al., 2008; AriasEstévez, 2008).

The agrochemical Ronstar 250 BR, Karate 50 EC and Sportak 450 EC were ranked as of very high-persistence leaching. In this study, Targa 50 and EC Benlate 500 were classified as high-persistence, while Totril, Dicarsol 500 and Dithane PM as low and very low-persistence, leaching, respectively (Table 3 ).

The runoff persistence of Ronstar 250 BR, Totril, Dicarsol 500, Karate 50 EC, Sportak 450 EC, Dithane wp and Benlate 500 were classified as low and very low, respectively, while Targa $50 \mathrm{EC}$ classified as of high persistence in the runoff (Table 3).

Looking at persistence of these agrochemicals in the sandy soil of the semi-arid region of Brazil, these agrochemicals represent ability to develop considerable residual during a given period, by which the higher persistence have a higher risk of contamination, through leaching, volatilization or erosion of the soils (Dan et al., 2010).

Anyusheva et al. (2016) reported that there is a great vulnerability of water due to the greater persistence of agrochemicals, regarding to runoff and leaching in particular during the application of agrochemicals. To protect the water resources, it is necessary to perform a series of actions. The proper management of the crops is responsibility of the producers, whose they use appropriate products specifically registered for the crop and applied according to the recommendations of professionals in the agricultural area (Capri and Karpouzas, 2008).

In the current study, the soil texture relevant to leaching and runoff were classified as high and low, respectively. The content of organic matter present in the soils of the region is low. The semiarid region has very low rainfall intensity and the rainfall; however, in the region the cultural practices in cultivation of onion is considered to be high (Table 3 ). These factors contribute to the fact that the agrochemicals are even more persistent and cause further damage to the environment in the region studied.

Augustus (2003) reported that the intensive use of agrochemicals in agricultural soils along with concentrated precipitation in just a time of year or even by the use of irrigation, leads to a strong surface runoff, contaminatingthe available water resources (Dabrowski et al., 2009, Zarate, 2010 and Zarate et al. 2011).

Alister end Kogan (2010) argued that there is a direct relationship between the precipitation and the rate of leaching and persistence of agrochemicals in the first 90 days of the application. This fact can be justified by the deep movement of agrochemicals in the soil during this time, which increases the dissipation in the soil layers, increasing soil degradation and water bodies.

\section{Grey water footprint for onion}

The grey water footprint (GWF) of agrochemicals currently being used in the cultivation of onion in a semi-arid region of the Brazilian (per hectare) is presented in Table 4. We noted that Targa $50 \mathrm{CE}$ has a great the fraction of leaching-flow value. Tthe Dithane PM was the one that evidenced the greatest total rate of application of the substance and load of pollutant in the substance. The maximum concentration was observed in the Benlate 500.

We observed that Dicarsol 500 HP has greater value of grey water footprint with value of $1500000 \mathrm{~m}^{3}$ (Table 4). Therefore, Dicarsol 500 HP requires the maximum volume of freshwater to assimilate the load of pollutants based on current environmental quality standards of water (Hoekstra and Chapagain, 2007; Hoekstra, 2011).

The grey water footprint (GWF) for an average productivity of 20 tons per hectare of onion in Brazilian semiarid region was $75078.0 \mathrm{~m}^{3} \mathrm{t}^{-1}$ (Table 4). This grey water footprint was calculated by taking the most critical the pollutant into consideration. The most critical pollutants are those that produce the largest volumes of polluted water (Muller, 2012; Olivatto, 2009). The most critical pollutant for GWF of onion is Dicarsol 500 PS (Table 4).

Mekonnen and Hoekstra (2011a; 2011b; 2015) estimated the grey water footprint of approximately $287.1 \mathrm{~m}^{3} \mathrm{t}^{-1}$ for the wheat culture. Silva et al., (2015) reported the value of 20.77 $\mathrm{m}^{3} \mathrm{ha}^{-1}$ for GWF of sugar cane in a dry-farming cultivation system. These results were well lower than those we found in our study. This mainly was due to the fact that a justified use agrochemicals were applied in this study, and also as a result of application rate and active ingredient of the agrochemical. Rivas Ibáñez et al. (2017) and Roux et al. (2016) reported a grey water footprint of $72 . \mathrm{m}^{3} \mathrm{t}^{-1}$ for the onion, well below that obtained in the present work. This is because they only took into consideration the already existed pollutants and they did not add the effect of applied agrochemicals. Also, in our study more rainfall is precipitated. Their lower GWF value also could be due to an underestimation of the water footprint.

The Water Pollution Level (WPL) is the fraction of the assimilative capacity of effluent consumed, which is calculated by the ratio between the largest grey water footprint for the culture of the onion and the flow of a real basin (Freal) from the Brazilian semiarid region. This level of pollution was $24.66 \%$, which is indicative of the sustainability of the basin as the largest pollutant found for the cultivation of onion. 
Mekonnen and Hoekstra (2015) reported a high water pollution level in various parts of the world, both by the presence of agrochemicals and concentration of nitrates, a fact that occur as a result of very low levels of runoff in these basins to assimilate the load of nitrates and agrochemicals. Hoekstra et al. (2011) asserted that $100 \%$ pollution level of water can indicate the capacity for fully assimilation of waste. However, when the pollution level exceeds $100 \%$, the quality standards of the water in its natural state are violated.

\section{Materials and Methods}

\section{Characterization of area}

The work was carried out in the Brazilian semi-arid zone in an area corresponding to 10 thousand hectares, located between the parallels of $7^{\circ} 0^{\prime}$ and $11^{\circ} 50^{\prime}$ South and between the meridians of $42^{\circ} 27^{\prime}$ e $37^{\circ} 0$ ' West, belong to the basin sub middle of the San Francisco river (Fig 1).

The climate of the region according to the classification of Köppen, is type BSwh' in a semi-arid, with average annual temperature of $27{ }^{\circ} \mathrm{C}$. The potential evapotranspiration is rated very high mainly in the north region, being of the order of 3,000 mm per year. In addition to high insolation and low relative humidity of the air, the dry season is predominant for 6 to 8 months. The rainfall is irregular and it is concentrated in 2 to 3 months of the year and the annual average is 400 to $650 \mathrm{~mm}$ (Cunha et al., 2008).

The part of the brazilian semi-arid region that encompasses the basin of the São Francisco river on the left bank is dominated by soils with medium texture the sandy and medium to very clayey in the right margin, being the class of soil predominant in the Latossolos and Argissolos (Embrapa, 2013).

The survey of the main agrochemicals used in the cultivation of onion was carried out. In addition, we considered the environmental conditions of soil, climate and management culture in the region of semi-arid, soon after we used mathematical models for the estimation of the grey water footprint (GWF) and sustainability for the region.

The grey water footprint (GWF) is calculated using the diffuse pollution. Because when a chemical substance is applied in the soil, only a part percolates to the surface and ground waters. Therefore, the mathematical models are applied that simulate these data of pollutant load in grams $(\mathrm{g})$ or milligrams (mg). According to Hoekstra et al. (2011), it is necessary to estimate the fraction of chemical that reaches to the water bodies through mathematical models.

The pollutants analyzed in this study were defined according to a questionnaire applied to farmers in the region, and data of the Institute of Agricultural Economics of Mato Grosso (IAEM). A herbicide, a fungicide and an insecticide were selected for the culture of the onion to determine the grey water footprint (GWF).

\section{Classification of agrochemical used on onions in Brazilian semi-arid region}

The maximum acceptable concentration (Cmax) of pollutants was obtained through legislation that deals with the water quality standards in its natural state. In the case of Brazil, CONAMA Resolution no. 357/2005 was used for fresh water Class II. The European Union laws (EU, 2013) have also been used, since these standards are current and are scientifically reliable according to Franke et al. (2013). The ordinance normative of IBAMA no. 84, 15 October 1996, defines the Potential Environmental Risk (PER) for products registered in Brazil. They are divided into classes that refer to the parameters of bioaccumulation, persistence, transport, toxicity to various organisms, potential mutagenic, teratogenic and carcinogenic, and are classified according to the Table 5. In this ordinance, the potential environmental risk (PER) is assigned to product features that promote contamination and damage to the compartments, biotic and abiotic features of ecosystems. The main agrochemicals used in the cultivation of onion in a semiarid region of the Brazilian were obtained from the Agronomic Institute of Pernambuco (IPA), among them, those found in Table 6.

The type of soil of the studied area determined the rate of leaching of the agrochemicals. The fraction of flow of leaching has been used to translate data on the amount of chemicals applied to the soil to estimate the amount of substances that enter the system from groundwater or surface water. The fraction was derived from the methodology proposed by Franke et al. (2013) and calculated for each chemical studied.

\section{The calculation of the grey water footprint for the culture of onion}

The grey water footprint (GWF) was calculated for each chemical used in onion cultivation in the semi-arid region of Brazil. The calculation was made by dividing the pollutant load ( $\mathrm{L}$, in mass/time) by the difference between the concentration of the environmental standard for a given pollutant (the maximum concentration acceptable cmax, in mass/volume) and its natural concentration in the receiving body (cnat, in mass / volume). The equation 1 was used for each chemical according to the method of Franke et al. (2013).

$$
G W F=\frac{L}{C_{\text {máx }}-C_{\text {nat }}}=\frac{a \times A p l}{C_{\text {máx }}-C_{\text {nat }}}
$$

Where; $A p l=$ the variable that represents the amount of chemical substances applied to the soil in a given process (mass / time);

$\mathrm{L}=$ pollutant load (mass / time);

Cmax = Maximum acceptable concentration (mass / volume); Cnat $=$ Natural concentration of the receiving body (mass / volume);

$\alpha=$ fraction of leaching or flow (dimensionless).

The dimensionless factor $\alpha$ represents the fraction of leaching or flow, defined as the fraction of applied chemicals that reach the bodies of water and can be calculated using Equation 2:

$$
\alpha=\alpha_{\text {mín }}+\left[\frac{\sum_{i} S_{i} x W_{i}}{\sum_{i} W_{i}}\right] x\left(\alpha_{\text {máx }}-\alpha_{\text {mín }}\right)
$$

Where: $\alpha \min =$ fraction of leaching $/$ minimum flow; $\alpha \max =$ maximum leaching fraction;

$\mathrm{Si}$ - leaching potential-flow;

$\mathrm{Wi}$ - factor weight.

The grey water footprint of crop $\left(\mathrm{GWF}, \mathrm{m}^{3} \mathrm{t}^{-1}\right)$ was calculated by multiplying the application rate per hectare of crop chemicals in the field (TQ, $\mathrm{Kg} \mathrm{ha}^{-1}$ ), by the fraction of leaching $(\alpha)$, divided by Cmax, $\mathrm{kg} \mathrm{m}^{-3}$ ) minus the natural concentration for the pollutant in question (Cnat, $\mathrm{kg} \mathrm{m}-3$ ) divided by the crop yield $\left(\mathrm{P}, \mathrm{t} \mathrm{ha}^{-1}\right)$ and Equation 3 . 
$G W F=\frac{(\alpha x T Q) /\left(C_{\text {máx }}-C_{n a t}\right)}{P}$

Where; GWF = grey water footprint $\left(\mathrm{m}^{3} \mathrm{t}^{-1}\right)$;

$\alpha=$ Fraction of leaching;

$\mathrm{TQ}=$ rate of application of chemical substances per hectare $\left(\mathrm{kg} \mathrm{ha}^{-1}\right)$;

Cmax = Maximum permissible concentration of the pollutant in the receiving aquatic environment $\left(\mathrm{kg} \mathrm{m}^{-3}\right)$;

Cnat $=$ Natural concentration of the pollutant in the receiving aquatic environment $\left(\mathrm{kg} \mathrm{m}^{-3}\right)$;

$\mathrm{P}=$ Productivity of the crop $\left(\mathrm{t} \mathrm{ha}^{-1}\right)$.

According to Hoekstra et al. (2011), an indicator of local impact is relevant to the calculation of the 'water pollution level' (WPL) in a basin, that measures the degree of pollution. It is defined as the fraction consumed from the assimilative capacity of the wastewater and calculated by the ratio between the grey water footprints of the total ( $\Sigma \mathrm{GWF})$ and the actual flow of a basin (Freal) according to the equation 4 .

$$
W P L[x, t]=\frac{\sum G W F[x, t]}{\operatorname{Freal}[x, t]}
$$

Where; WPL = 'water pollution level;

$\Sigma \mathrm{GWF}=$ total sum of grey water footprints;

Freal $=$ the actual flow of a basin.

The sustainability assessment of grey water footprint depends on the flows available in the basin to assimilate the wastewater and the specific time period that can be considered as critical point when the patterns of water in its natural state in that period and in that bowl are violated, when the capacity of assimilating waste is completely consumed.

\section{Conclusion}

The agrochemicals Ronstar 250 BR, Dicarzol 500 PS and Sportak $450 \mathrm{CE}$ were classified within highest grey water footprint for onion cultivation in the Brazilian semi-arid region. Therefore, they require a higher volume of freshwater for dilution of pollutants such that they become harmless. It is recommended to replace these agrochemicals with others of smaller GWF. According to the obtained results, it can be concluded that the grey water footprint is an efficient indicator in monitoring the impact of man on the environment. The semi-arid region of Brazil is classified as sustainable for the cultivation of irrigated onions. The determination of the grey water footprint for an onion culture was considered a tool capable of identifying the risks of contamination of fresh water by the excessive use of agrochemicals in the Brazilian semi-arid.

\section{Acknowledgement}

We thank CAPES and CNPq for their contribution to the research.

\section{References}

Aktar MW, Sengupta D, Chowdhury A (2009) Impact of pesticides use in agriculture: their benefits and hazards. $\mathbf{J}$ Interdiscip Toxicol. 2(1): 1-12.

Alister C, Kogan M (2010) Rainfall effect on dissipation and movement of diuron and simazine in a vineyard soil. Plantas Daninhas. 28:1059-1071.
Anyusheva M, Lamers MN, Nguyen VV, Streck T (2016) Persistence and leaching of two testicides in a paddy soil in northern vietnam. Clean Soil Air Water. 44(7): 1-9.

Arias-Estevez M, Lopez-Periago E, Martínez-Carballo E, Simal-Gandara J, Mejuto J, Garcia-Ri OL (2008) The mobility and degradation of pesticides in soils and the pollution of groundwater resources. Agric Ecoss and Environ.123(4):247-260.

Augusto LGS (2003) Uso dos agrotóxicos no semi-árido brasileiro. In: Fiocruz, 73.

Bernabeu A, Vercher RF, Santos-Juanes L, Simón PJ, Lardín C, Martínez MA, Vicente JA, Gonzalez R, Llosa C, Arques A, Amat AM (2011) Solar photocatalysis as a tertiary treatment to remove emerging pollutants from wastewater treatment plant effluents. Catal Today. 161(1): 235-240.

Canuto TG, Gama AF, Barreto FMS, Alencar Neto MFA (2010) Estimativa do risco potencial de contaminação por pesticidas de águas superficiais e subterrâneas do município de Tianguá-CE com aplicação do método de GOSS e índice de GUS. Trabalho apresentado no 17 Congresso brasileiro de águas subterrâneas e 16 encontro nacional de perfứrddores de poços, São Luis, ABAS, 01-05 de outubro de 2010

Capri E, Karpouzas D (2008) Pesticide risk assessment in rice paddies: theoryand practice. Elsevier Science and Technology , Amsterdam. 266.

Carbo L, Souza V, Dores EFGC, Ribeiro ML (2008) Determination of pesticides multiresidues in shallow groundwater in a cotton-growing region of Mato Grosso, Brazil J Braz Chemc Soc. 19(6): 1111-1117.

Cunha TJF, Silva FHBB, Silva MSL, Petrere VG, Sá IB, Oliveira Neto MB, Cavalcanti AC (2008) Solos do submédio do vale do são francisco: potencialidades e limitações para uso agrícola. In: Embrapa, Petrolina, 60.

Dabrowski JM, Murray K, Ashton PJ, Leaner JJ (2009) Agricultural impacts on water quality and implications for virtual water trading decisions. Ecol Econ. 68(4): 10741082.

Damalas A, Velimezi G, Kalaitzakis A, Liontos M, Papavassiliou AG, Gorgoulis V (2011) Loss of p14(ARF) confers resistance to heat shock- and oxidative stressmediated cell death by upregulating $\beta$-catenin. Int $\mathrm{J}$ Cancer.128(8):1989-1995.

Dan HA, Dan LGM, Barroso ALL, Procópio SO, Oliveira Junior RS, Assis RL, Silva AG, Feldkircher C (2010) Seletividade do herbicida tembotrione a cultura do milheto. Plantas Daninhas. 28(4):793-799.

Dourte DR, Fraisse CW (2012) What is a water footprint?: an overview and applications in agriculture, s.l.: University of Florida Cooperative Extension Service, Institute of Food and Agriculture Sciences, EDIS, IFAS. 1:1-11.

Embrapa - Empresa Brasileira de Pesquisa Agropecuária (2013) Sistema brasileiro de classificação de solos. 3.nd. Brasília. 353

Ercin AE, Aldaya MM, Hoekstra AY (2012) The water footprint of soy milk and soy burger and equivalent animal products. Ecol Indic. 18: 392-402.

Faria MV, Morales RGF, Resende JTV, Zanin DS, Menezes CB, Kobori RF (2012) Desempenho agronômico e heterose de genótipos de cebola. Hort Bras. 30(2): 220-225.

Franke NA, Boyacioglu H, Hoekstra AY (2013) Grey water footprint accounting: Tier 1 supporting guidelines. In: Unesco-Ihe Institute for Water Education, 1nd, Delft. 65p.

Gibson G, Koifman S (2008) Agricultural toxic use and temporal distribution of male birth rate in the state of Parana, Brazil. Rev Panam Salud Publica. 24(4): 240-247. 
Hoekstra AY, Chapagain AK (2007) Water footprints of nations: Water use by people as a function of their consumption pattern. Water Resour Manage. 21(1):35-48.

Hoekstra AY, Chapagain AK, Aldaya MM, Mekonnen M (2011) The water footprint assessment manual: setting the global standard. In: Earthscan, 14 nd, London. 228p.

Hoekstra AY (2009) Human appropriation of natural capital: A comparison of ecological footprint and water footprint analysis. Ecological Economics. 68(7): 1963-1974.

Mekonnen MM, Hoekstra AY (2011a) The green blue and grey water footprint of crops and derived crop products. Hydrol Earth Syst Sci. 15:1577-1600.

Mekonnen MM, Hoekstra AY(2015) Global grey water footprint and water pollution levels related to anthropogenic nitrogen loads to fresh water. Environ Sci Technol. 49(21):12860-12868.

Mekonnen MM and Hoekstra AY (2011b) National water footprint accounts: the green, blue and grey water footprint of production and consumption. Value of water research report series, no. 50. UNESCO-IHE.

Molozzi J, Pinheiro A and Silva MR (2006) Qualidade da água em diferentes estádios de desenvolvimento do arroz irrigado. Pesq Agropec Bras. 41(9): 1393-1398.

Muller GT (2012) Emprego da pegada hídrica e da análise de ciclo de vida para a avaliação do uso da água na cadeia produtiva do biodiesel de soja. Universidade Federal do Rio Grande do Sul, Porto Alegre. 188.

Nyambo P, Wakindiki IIC (2015) Water footprint of growing vegetables in selected smallholder irrigation schemes in South Africa. Afr J Online. 41(4): 5571-578.

Olivatto LM (2009) Análise da eficiência de estação de tratamento de efluentes em indústria de extração de óleo de soja e proposições de novas metodologias de análises e tratamentos. Universidade de São Carlos, Sorocaba. 100.

Pinheiro A, Moraes JCS and Silva MR (2011) Pesticidas no perfil de solos em áreas de plantação de cebolas em Ituporanga, SC. Rev Bras Eng Agríc Ambient. 15(5):533538.

Rivas Ibáñeza G, Molina Ruíz BJM, Román Sánchez MI, Casas Lópeza JL (2017) A corporate water footprint case study: The production of Gazpacho, a chilled vegetable soup Water Resour and Industry. 17: 34-42.
Roux BL, Vahrmeijer T, Keith L, Bristow KL (2016) Estimating water footprints of vegetable crops: influence of growing season, solar radiation data and functional unit. Water. 8(10): 473-493.

Salmoral G, Aldaya MM, Chico D, Garrido A, Lamas MR (2011) The water footprint of olives and olive oil in Spain. Spanish J Agric Res. 9: 1089-1104.

Silva VPR, Albuquerque MF, Araújo LE, Campos JHBC, Garcêz LSA, Almeida RSR (2015) Medições e modelagem da pegada hídrica da cana-de-açúcar cultivada no Estado da Paraíba. Rev Bras Eng Agríc Ambient. 19(6):521-526.

Silva VPR, Aleixo DO, Dantas Neto J, Maracajá KFB, Araújo LE (2013) Uma medida de sustentabilidade ambiental: pegada hídrica. Rev Bras Eng Agríc Ambient.17(1):100-105.

Spadotto CA, Gomes MAF, Luchini LC and Andréa MM (2004) Monitoramento do risco ambiental de agrotóxicos: princípios e recomendações. 1nd. Embrapa Meio Ambiente (Documentos 42), Jaguariúna, 29.

Tavella LB, Silva IN, Fontes LO, Dias JRM, Silva MI (2011) $\mathrm{O}$ uso de agrotóxicos na agricultura e suas consequências toxicológicas e ambientais. ACSA. 7(2):6-12.

UE Directive (2013) Of the european parliament and of the council amending directives 2000/60/ec and 2008/105/ec as regards priority substances in the field of water policy. European Union. Brussels. Belgium. 5:100-120.

Van Oel PRV, Hoekstra AY (2012) Towards quantification of the water footprint of paper: a first estimate of its consumptive component. Water Resour Manage. 26(3):733-749.

Zarate E, Zeng Z, Hoekstra AY (2011) Grey water footprint as an indicator of levels of water pollution in the production of organic vs. conventional cotton in India", water footprint network in collaboration with C\&A and cotton connect, Enschede, The Netherlands.103.

Zarate E (ed) (2010). WFN grey water footprint working group final report: a joint study developed by WFN partners, water footprint network, Enschede, Netherlands.97.

Zhao X, Chen B, Yang Z F (2009) National water footprint in an input-output framework-a case study of China 2002. Ecological Modelling. 220(2):245-253. 